\title{
29 Updated Perspectives on the International Legal Environment for Selection
}

Winny Shen, Paul R. Sackett, Filip Lievens, Eveline Schollaert, Greet Van Hoye, Dirk D.

Steiner, Florence Rolland, Konstantina Georgiou, Ioannis Nikolaou, Maria Tomprou, Shay Tzafrir, Peter Bamberger, Marilena Bertolino, Marco Mariani, Franco Fraccaroli, Tomoki Sekiguchi, Betty Onyura, Hyuckseung Yang, J.K. Oostrom, Paul Englert, Oleksandr Chernyshenko, Hennie J. Kriek, Tina Joubert, Jesús F. Salgado, Annika Wilhelmy, Cornelius J. König, Aichia Chuang, and Mark Cook ${ }^{1}$

In the United States, the legal context plays a major role in how industrial/organizational (I/O) psychologists approach selection system development. The set of protected groups, the approaches to making an a priori case of discrimination (e.g., differential treatment vs. adverse impact), the key court cases influencing selection, and the prohibitions against preferential treatment (e.g., the 1991 ban on score adjustment or within-group norming) are well known. Selection texts (e.g., Guion, 1998) and human resource management texts (e.g., Cascio \& Aguinis, 2008) give prominent treatment to the legal context. In recent years, there has been a growing internationalization of I/O psychology such that psychologists from all over the world work with clients in other countries and contribute to our journals and to our conferences. Test publishers and consulting firms establish offices globally. As this internationalization continues, it becomes increasingly useful to take a broader look at the legal environment for selection, examining similarities and differences in various countries. For example, consider a U.S firm with operations in several other countries. Although U.S.

\footnotetext{
${ }^{1}$ All authors contributed equally to this chapter. Winny Shen and Paul Sackett integrated the text materials provided by each author. Portions of this chapter were previously drawn from an article by the same set of authors: Myors, B., Lievens, F., Schollaert, E., Van Hoye, G., Cronshaw, S. F., Mladinic, A., et al. (2008). International perspectives on the legal environment for selection. Industrial and Organizational Psychology: Perspectives on Science and Practice, 1, 200-256. Used by permission of the Society for Industrial and Organizational Psychology and Wiley Blackwell.
} 
fair employment law applies only to those overseas employees who are U.S. citizens or foreign nationals employed in the U.S. by a U.S.-based firm, the employment by U.S. firms of host country nationals or third country nationals is subject to the legal environment of the host country.

\section{DATA COLLECTION METHODOLOGY}

To compare and contrast the legal environment for selection in various countries, the senior author prepared a set of questions about the legal environment for selection, prepared model answers describing the legal environment in the United States, and contacted psychologists in various countries, asking them to prepare a document describing the legal environment in their countries. The goal was to obtain a range of perspectives by sampling about 20 countries. Thus, this chapter is by no means a complete catalog of the legal environment around the world. Researchers and practitioners who are experts on the topic of selection participated from the following 22 countries in the original chapter and updated information was obtained for 17 of these countries (denoted in asterisks) for this revision: Australia, Belgium*, Canada*, Chile, France*, Germany, Greece*, India, Israel*, Italy*, Japan*, Kenya*, Korea*, The Netherlands*, New Zealand*, South Africa*, Spain*, Switzerland*, Taiwan*, Turkey, the United Kingdom*, and the United States*. As the list indicates, the countries covered do broadly sample the world. Because of space constraints, the results for each country were summarized and organized by issue rather than by country to create this chapter. For more context on the legal, social, cultural, and political environment of the countries surveyed, see Myors et al. (2008). Contributing authors from each country responded to several questions, nine of which are addressed in turn in this chapter. 
Question 1: Are there racial/ethnic/religious subgroups such that some are viewed as "advantaged" and others as "disadvantaged"?

The disadvantaged groups identified by country differ on several dimensions. First, the basis for disadvantaged status varies: (a) native/aboriginal people in a setting where colonizers became the majority group (e.g., Native Americans in the United States; Mäori in New Zealand; First Nations Peoples, Metis, and Inuit in Canada), (b) recent immigrants (e.g., people from the Middle East moving to many European countries), (c) racial/ethnic groups either native to or with long histories in the country (e.g., African Americans in the United States; Blacks, colored individuals, and Indians in South Africa; less populous ethnic tribes in Kenya), (d) religious groups (e.g., India), and (e) language groups (e.g., Francophones in Canada; Rhaeto-Romanic speakers in Switzerland). Second, the size of the minority population varies, from a very small percentage of the population in some countries to the South African extreme of a previously disadvantaged Black majority. Overall, there is considerable variability from country to country in what constitutes a disadvantaged group. We refer interested readers to the first edition of this Handbook chapter (i.e., Sackett et al., 2010) for additional details regarding specific disadvantaged groups for each country.

Question 2: What is the general picture regarding women in the workplace (e.g., historical trends regarding employment for women; current data on percentage of women in the workforce; and current status regarding occupational segregation, such as gender representation in various job classes and at various organizational levels)?

Among the countries surveyed, women make up a substantial portion of the workforce (ranging from approximately 30-70\%). Strides have been made such that women are increasingly involved in the workforce across all countries surveyed, as evidenced by women's generally high rates of participation in the workforce (ranging from 38-69\%). These 
differences are undoubtedly at least partially due to the multitude of differences among countries including those in history, culture and values, economic conditions, and political conditions. It is interesting to note that in no instance is the female participation rate higher than the male participation rate; this may partially reflect the traditional division of labor between men and women. Furthermore, although women are less likely to participate in the workforce than their male counterparts, it appears that there tends to be no or small differences in the unemployment rate for men and women (usually within 1 or 2 percentage points). Exceptions to this general trend include Greece, Kenya, and Switzerland, where women are still substantially more likely to be unemployed then male workers.

Among all nations surveyed, there is still gender disparity in pay that is substantial in magnitude (ranging from 66 to $88 \%$ ). Although it is unclear as to whether these estimates take into account factors such as differences in occupations, full- versus part-time work, and educational attainment, other research has shown that even taking into account some of these factors, women still earn less than their male counterparts (though the gap generally decreases; e.g., U.S. General Accounting Office, 2003). Furthermore, there continues to be occupational segregation to some extent in all countries surveyed, and women are still more likely to join the workforce as part-time workers in many countries (e.g., Belgium, France, Germany, Israel, Japan, Switzerland, the Netherlands, and the United Kingdom). Generally, women are more likely to be found in clerical or secretarial, retail or sales, healthcare, education, public services, or small-scale agricultural farming occupations than their male counterparts. The occupations that women are most heavily concentrated in also tend to be in the lower income segment. Finally, women remain underrepresented in business and management positions as well as technical and scientific, professional, and high-level government positions (e.g., judges and cabinet members), particularly at more senior levels. 


\section{Question 3: Is there research documenting mean differences between groups on individual difference measures relevant to job performance?}

Mean differences on ability and personality measures are commonly examined in the United States, with enough data for large-scale meta-analytic summaries (e.g., Roth, Bevier, Bobko, Switzer, \& Tyler, 2001; Foldes, Duehr, \& Ones, 2008). Mean differences on tests of developed cognitive abilities of roughly 1.00 standard deviation (SD) between Whites and African Americans and roughly 0.67 SD between Whites and Hispanics have been consistently reported (Roth et al., 2001). This abundance of data proves to be in marked contrast to the pattern of findings in the countries examined here. In fact, for most countries, the authors reported finding either no research or research with samples so small that they generally refrained from drawing conclusions.

Although limited, for a few countries, research on group differences on measures of cognitive ability is available. Generally, the research to date shows the advantaged group typically scores higher on tests of cognitive ability than the aboriginal group (e.g., aboriginal groups in Australia, Canada, New Zealand, and Taiwan). The available data also suggest that advantaged groups often score higher than recent immigrants on cognitive ability tests (i.e., Dutch vs. Turkish/Moroccan and Surinamese/Antillean immigrants in the Netherlands, and Belgians vs. Moroccan/Turkish immigrants in Belgium), though these differences may be driven, in part, by language as group differences generally decreased when comparing the advantaged group to second- versus first-generation immigrants. In South Africa, mean score differences on cognitive tests between Black and White groups are normally larger than U.S. studies, with Whites obtaining the higher mean scores. In Israel, mean score differences between Jews and Arabs on college admissions tests favor the Jewish majority. Please see the first edition Handbook chapter (i.e., Sackett et al., 2010) for additional details regarding these studies. 
Data on personality measures are even more limited than for cognitive ability, with authors reporting personality data from only two countries: studies of Black-White differences in South Africa generally showing small differences (Joubert \& Venter, 2013; Kriek, 2006), and several studies of Dutch-immigrant differences in the Netherlands showing much larger differences (De Soete, Lievens, Oostrom, \& Westerveld, 2013; te Nijenhuis, van der Flier, \& van Leeuwen, 1997, 2003; van Leest, 1997). Research examining gender differences in selection constructs and tools was also scarce in most countries, and research investigating group differences in job performance was virtually non-existent outside the U.S.

Overall, several findings of interest emerge. First, it is clear that gathering data and reporting mean differences by group is far more common in the United States than in virtually all of the countries contributing to this report. This outcome is likely the result of the legal scrutiny to which tests are held in the United States. The Uniform Guidelines on Employee Selection Procedures (U.S. Equal Employment Opportunity Commission, 1978) use adverse impact computations as the basis for a prima facie case of discrimination, and thus, adverse impact resulting from test use is routinely examined, with mean differences between groups and the method of test use (e.g., a high or a low cutoff) functioning as key determinants of adverse impact. Second, although data tend to be sparser than in the United States, group differences have been studied and observed in various settings involving different types of disadvantaged groups. Third, as in the United States, there is interest not only in whether there are group differences, but also in understanding the basis for these differences. Language, culture, and differences in educational access and attainment are seen as key concerns in understanding differences in test scores across groups.

In the United States, disparate impact is the basis for a prima facie case of discrimination. The implicit assumption is that various groups are expected to obtain similar mean scores absent bias in the measure. Reports from European country authors suggest that many 
European countries target certain groups as immigrants to meet specific labor shortages. Thus, immigrants might have higher or lower abilities, depending whether a country tried to attract highly skilled people (e.g., recent immigrants into Switzerland from northern and western Europe) or tried to attract people with low skills (e.g., Turkish immigrants to Germany). In other words, even if one has a general expectation of no group differences at the population level, a finding of differences between locals and immigrants would be expected given this targeted immigration.

\section{Question 4: Are there laws prohibiting discrimination against specific groups and/or mandating fair treatment of such groups? Which groups are protected? Which employers are covered? Which employment practices are covered (e.g., selection, promotion, dismissal)?}

Table 29.1 presents summary information addressing the above questions for each country. Several findings emerge. First, there is some basis for legal protections for members of specified groups in all countries. The bases for these protections vary widely. In many cases the national constitution provides general, or at times specific, protections. This may be seen as analogous to the 5th and 14th Amendments to the U.S. Constitution, which respectively state that "no person shall ... be deprived of life, liberty, or property without due process of law," and that "no state shall ... deny to any person within its protection the equal protection of the laws." However, in virtually all cases there are also specific laws defining specified protected classes, specifying which employment practices are covered and which employers are required to comply. The intent here is to identify the major contemporary federal laws and government decrees, and as such it is not a complete record of all historical employment regulations. Additionally, several states and cities have additional statutes offering protection to groups beyond those covered by national law. 
Second, the protections offered are generally quite sweeping in terms of the types of employers covered and the range of employment practices included. In most cases all employers are covered. Some laws are restricted to government employees, and in some cases, coverage is restricted to larger employers, with the coverage threshold varying quite widely for some statutes (e.g., 6 employees in Israel [though the equal pay law is required of all organizations], 15 in the U.S., 100 in Taiwan, and 300 in Korea). It is also typical for a broad range of employment practices to be included. For example, employee selection is specifically included in all countries except Chile, which has the least developed set of employment rights regulations examined here (though discrimination based on protected class status is prohibited in Chile, just which employment practices are covered is unclear).

Third, there is both convergence and divergence in the classes that receive protection in each country. Table 29.2 identifies the most common protected classes and indicates whether those classes are covered in each of the contributing countries. The classes covered in U.S. Civil Rights law emerge as widely commonly covered across countries: race, color, religion, gender, national origin, age, and disability status. Three categories not protected by federal statute in the United States are protected in most countries: political opinion, sexual orientation, and marital/family status. Several protected classes are covered in only a few countries or are unique to a few countries; Table 29.3 identifies these less commonly protected classes. Examples include language, appearance, union membership, socioeconomic status, genetic information, and irrelevant or pardoned criminal record.

\section{Question 5: What is required as prima facie evidence of discrimination? What is required to refute a claim of discrimination?}

In most countries, direct (e.g., differential treatment) and indirect (e.g., disparate impact) prima facie evidence of discrimination are acknowledged. In India, disparate impact is 
necessary but not sufficient to prove a case of discrimination; underrepresentation must be shown to be due to historical social or religious discrimination toward a particular group. Only two countries require evidence of the intent to discriminate, Taiwan and Turkey, thus ruling out a disparate impact theory of discrimination.

However, although disparate impact evidence can be used as evidence in most countries, highly specific evidentiary rules used in the United States (e.g., the four-fifths rule and tests of the statistical significance of the difference between passing rates for various groups) are generally not in use (Canada, is an exception, because cases using the four-fifths rule in the United States have been used to make a case for a similar standard). Commentators note that in most cases there are few or no cases involving disparate treatment challenges to predictors commonly used by psychologists, and thus, there is not the extensive case law that has developed in the United States. Recall that the four-fifths rule in the United States derives from guidelines issued by enforcement agencies, and the use of significance testing derives from case law; neither the concept of disparate impact nor the mechanisms for identifying its presence are contained in a statute. Absent a history of challenges resulting in case law, it is not surprising to see the lack of specificity as to evidentiary standards.

A similar lack of specificity applies to the question of what is required to refute a claim of discrimination. Table 29.4 summarizes information across countries. In general, there is some version of the shifting burden of proof model in countries where disparate impact evidence is permissible. After a prima facie showing, the burden to justify the use of the employment practice shifts to the employer in all countries except Switzerland, where the burden of showing that the practice is not job-related is only partially reduced or remains with the plaintiff. There is a general notion that the employer should present evidence to support the job relatedness of the employment practice in question, but rarely is the required form of such evidence specified (e.g., use of validity evidence to establish job relatedness). 


\section{Question 6: What are the consequences of violation of the laws?}

Table 29.4 also summarizes possible consequences of violation in each participating country. There is considerable variation in the array of possible remedies. As a point of reference, note that in the United States the focus is on compensatory or "make-whole" remedies, with punitive damages reserved for instances of intentional discrimination. Similarly, make-whole remedies are part of the landscape in all countries for which information could be obtained. Several countries also provide fines and punitive damages (e.g., Switzerland and Turkey), and several include imprisonment as a possible consequence (e.g., Belgium, France, and Greece).

\section{Question 7: Are particular selection methods limited or banned as a result of legislation or court rulings?}

There are relatively few restrictions on specific selection methods. As a point of reference, U.S. law regulates the use of the polygraph, prohibiting its use for most private employers; several other countries restrict polygraph use as well (e.g., Germany, Israel, and Turkey). The only selection method specifically mentioned in U.S. law is the reference in the Tower amendment to Title VII of the Civil Rights Act of 1964 (U.S. Code, 1964) to the permissibility of professionally developed ability tests, provided that such tests are not designed, intended, or used to discriminate. Additional instances reported of restrictions on specific selection methods in participating countries include a prohibition against comprehensive personality assessment in Switzerland and a restriction on the use of certain Minnesota Multiphasic Personality Inventory (MMPI) and California Psychological Inventory (CPI) items in Spain. In Israel, recent Labor Court rulings have made the use of graphology for selection risky and potentially problematic for employers, though its use is 
still technically legal.

The most strikingly different approach to regulating selection practices is found in South Africa. Rather than the common approach of a presumptive right of an employer to use a particular method absent a successful challenge by a plaintiff, South African law puts the burden immediately on the employer. According to the Employment Equity Act of 1998 (Government Gazette, 1999), psychological testing and other similar assessments are prohibited unless the test is proven to be scientifically valid and reliable, can be applied fairly to all employees, and is not biased against any employee or group. The Society for Industrial and Organizational Psychology in South Africa (SIOPSA) published "Guidelines for the Validation and Use of Assessment Procedures for the Workplace" during 2005 to provide guidelines for practitioners in the field of I-O psychology to ensure that their assessment instruments and practices comply with the scientific requirements and international best practices. These guidelines were largely based on the American SIOP Principles. Given more recent amendments to the act (as amended in July 2014), employers are now also required to register instruments that measure psychological constructs with the Health Professionals Council of South Africa before they may be used in the employment setting.

Similarly, in The Netherlands, the Dutch Committee on Tests and Testing (COTAN), which is a committee of the Dutch Association of Psychologists (Nederlands Instituut van Psychologen), audits the quality of psychological tests that are available for use in the Netherlands (Evers, Sijtsma, Lucassen, \& Meijer, 2010). Currently, the COTAN has evaluated over 750 tests, including intelligence tests, personality assessments, and occupational tests. Starting this year, COTAN will also evaluate tests on their evidence of fairness as one of their criteria, suggesting that investigations of differential prediction and group differences may become more commonplace for assessments used in The Netherlands. However, note that employers are legally allowed to use tests that have been rated as 
insufficient by the COTAN, though it appears that ratings by COTAN are beginning to carry substantial weight with employers, particularly government and financial institutions.

\section{Question 8: What is the legal status of preferential treatment of members of minority groups (e.g., quotas or softer forms of preference)?}

To set the stage, note that the term "affirmative action" is used in various contexts, only some of which involve preferential treatment for protected groups. Some forms of affirmative action involve outreach efforts to publicize openings and to encourage applications from members of protected groups without preferential treatment given once an individual is in the applicant pool. Approaches involving preferential treatment fall into two main classes: (a) those that set differing standards for protected and nonprotected groups without setting aside a specified number or proportion of openings for members of protected groups (e.g., different cut-off scores, within-group norming) and (b) quota approaches that set aside a fixed number or proportion of openings for members of protected groups.

Table 29.4 summarizes the status of preferential treatment in the participating countries. Preferential treatment is a domain in which the United States emerges as a clear outlier. Preferential treatment in terms of differing score cutoffs or separate norming of tests within group is prohibited by the U.S. Civil Rights Act of 1991 (U.S. Code, 1991), and the use of quotas is restricted to very limited settings, such as a court-ordered remedy following a finding of discrimination. In contrast, preferential treatment in some form is typically allowed, at least for some groups, in almost all countries surveyed. Several commentators noted that applying lower standards to protected groups (e.g., different cutoffs or withingroup norming) is used for selection but not for promotion decisions (e.g., Australia, South African, and India). The status of quotas also varies substantially across contexts, from prohibited (Australia), to permitted and widely used (South Africa), to used in government 
sectors (backward classes in India and women in Chile), to required for certain groups (e.g., aborigines in Taiwan, individuals with disabilities in France, Japan, Kenya, Korea, and Taiwan). Since our original Handbook chapter was published, several European countries have adopted the use of quotas to increase the number of women in high-level government positions, including among elected public officials (e.g., Belgium and France).

\section{Question 9: How have laws and the legal environment affected the practice of science- based employee selection in this country?}

In only a few countries (i.e., Canada, South Africa, and the United States) is the legal environment seen as having a large effect on science-based employee selection. In general, the separation between legal issues and science-based practice can be attributed partially to the much more amorphous legal standards and consequences with regards to employment discrimination in most countries surveyed. However, the reciprocal relationship between science-based selection and the legal environment will need to continue to be monitored because many countries are still in the process of developing legal statutes and requirements or establishing guidelines for prosecution and rulings on employment discrimination.

Overall, most employers in the countries surveyed have great latitude in choosing what selection procedures to utilize. However, most employers are aware of the social and political nature of selection procedures and seem to err on the side of mainstream, popular, and usually well-validated selection methods. The most common type of selection procedures do vary by country. It is common to see reports of increased use of the tools and techniques of science-based selection, but the driving forces appear more commonly to be the presence of multinational firms and consulting firms that import these techniques into the country. 


\section{DISCUSSION}

In the original version of this chapter, we offered 35 broad summary statements about the patterns emerging from the narratives from the countries surveyed (e.g., although every country has a law or directive that prevents discrimination on the basis of sex or race/ethnic origin, in many countries few cases are actually filed or brought to trial because workers do not understand their rights or because the evidence needed to establish discrimination is not clear). It appears that over the subsequent five to seven years, the landscape regarding the legal environment for selection has remained more similar than different. This is not entirely surprising given that it typically takes time for countries to alter their employment policies, regulations, and laws. Thus, we believe that our prior summaries and conclusions generally still stand and we encourage interested readers to revisit our original chapter for these specifics (Sackett et al., 2010, pp. 673-675).

In looking forward, we asked commentators to identify trends that they see emerging for both selection more generally as well as specifically with regards to the legal environment for selection. Several commentators noted the increased use of new technologies by organizations for recruitment and selection, particularly social media, and that doing so may bring to the forefront new concerns regarding privacy as well as to what information the employer can and should have access about applicants. Many commentators also believe that concerns about fairness and discrimination will continue to grow. In particular, commentators in countries that have recently adopted new policies (e.g., more aggressive affirmative action efforts in Kenya) are curious as to whether and to what extent these laws will be effective in promoting greater representation of historically disadvantaged groups in the workplace. Other commentators highlight that laws may be insufficient in bringing about change if minority groups lack faith in mainstream institutions, which may need to be more proactive in their 
enforcement of anti-discrimination laws in order to change the public's perception. Finally, given the ongoing global refugee crisis, the large influx of migrants, particularly in many European countries, may ultimately serve to substantially alter the prevalence of disadvantaged groups and the nature of such group in many countries in the future.

In conclusion, this compilation of information about perspectives from a wide range of countries should be a valuable resource to students, researchers, and practitioners around the globe as a starting point for further research and improved practice. We encourage international collaborations on other workplace issues, and hope this project provides a useful model of an effective partnership.

\section{REFERENCES}

Cascio, W. F., \& Aguinis, H. (2008). Applied psychology in human resource management (6th ed.). Upper Saddle River, NJ: Pearson Education.

De Soete, B., Lievens, F., Oostrom, J., \& Westerveld, L. (2013). Alternative predictors for dealing with the diversity-validity dilemma in personnel selection: The constructed response multimedia test. International Journal of Selection and Assessment, 21, 239250.

Evers, A., Sijtsma, K., Lucassen, W., \& Meijer, R. R. (2010). The Dutch review process for evaluating the quality of psychological tests: History, procedure, and results. International Journal of Testing, 10, 295-317.

Foldes, H. J., Duehr, E. E., \& Ones, D. S. (2008). Group differences in personality: Metaanalyses comparing U.S. racial groups. Personnel Psychology, 61, 579-616.

Government Gazette. (1999). Employment Equity Act, 1998 (Act No. 55 of 1998), R 1360.

Guion, R. M. (1998). Assessment, measurement, and prediction for personnel decisions. Mahwah, NJ: Lawrence Erlbaum. 
Joubert, T. \& Venter, N. (2013). The Occupational Personality Questionnaire. In: S. Laher \& K. Cockroft (eds.), Psychological Assessment in South Africa. Johannesburg, SA: Wits University Press.

Kriek, H. J. (2006). Personality assessment: Group differences, language proficiency and fairness. Presented at the Society of Industrial and Organizational Psychology Conference, May 2006, Dallas, TX.

Myors, B. (2003). Within-group norming: Just because it's illegal in America, doesn't mean we can't do it here. Paper presented at the 5th Australian Conference on Industrial/Organisational Psychology, Melbourne, Australia.

Myors, B., Lievens, F., Schollaert, E., Van Hoye, G., Cronshaw, S. F., Mladinic, A., et al. (2008). International perspectives on the legal environment for selection. Industrial and Organizational Psychology: Perspectives on Science and Practice, 1, 206-256.

Roth, P. L., Bevier, C. A., Bobko, P., Switzer, F. S., \& Tyler, P. (2001). Ethnic group differences in cognitive ability in employment and educational settings: A meta-analysis. Personnel Psychology, 54, 297-330.

Society for Industrial and Organisational Psychology in South Africa. (2005). Guidelines for the validation and use of assessment procedures for the workplace. Retrieved on June 7, 2007, from http://www.siopsa. org.za

te Nijenhuis, J., van der Flier, H., \& van Leeuwen, L. (1997). Comparability of personality test scores for immigrants and majority group members: Some Dutch findings. Personality and Individual Differences, 23, 849-859.

te Nijenhuis, J., van der Flier, H., \& van Leeuwen, L. (2003). The use of a test for neuroticism, extraversion, and rigidity for Dutch immigrant job-applicants. Applied Psychology: An International Review, 52, 630-647.

U.S. Code. (1964). Pub. L. 88-352. 
U.S. Code. (1991). Pub. L. 102-166.

U.S. Equal Employment Opportunity Commission. (1978). Uniform guidelines on employee selection procedure. 29 CFR 1607.1. Washington, DC: Author.

U.S. Office of General Accounting. (2003). Women's earnings: Work patterns explain difference between men and women's earning. Retrieved on June 20, 2008, from http://usgovinfo.about.com/gi/dynamic/offsite.

htm?zi=1/XJ\&sdn=usgovinfo\&cdn=newsissues\&tm=110\&gps=64_261_1276_825\&f=00 $\& \mathrm{tt}=2 \& \mathrm{bt}=0 \& \mathrm{bts}=0 \& \mathrm{zu}=\mathrm{http} \% 3 \mathrm{~A} / / \mathrm{www} \cdot$ gao.gov/new.items/d0435.pdf

van Leest, P.F. (1997). Persoonlijkheidsmeting bij allochtonen [Assessment of personality for ethnic minorities]. Lisse, The Netherlands: Swets \& Zeitlinger. 
TABLE 29.1

International Laws and Practices

\section{Country}

Australia

Canada

Chile

\section{Law}

The Crimes Act 1914

Racial Discrimination Act 1975

Sex Discrimination 1984

Human Rights and Equal Opportunity Commission Act 1986

Disability Discrimination Act 1992

Workplace Relations Act 1996

Equal Opportunity for Women in the Workplace Act 1999

Age Discrimination Act 2004

Belgian Constitution of 1994 Article 10, 11, 191

Law Equality of Men-Women of 1978

Anti-Racism Law of 2003

Antidiscrimination Law of 2007

Canadian Human Rights Code of 1985

Section 15 of the Charter of Rights and Freedoms (1982)

Federal Employment Equity Act (2004)

Federal Contractors Program

Pay equity legislation (federal and some provinces)

Constitution, Chapter 3 (Rights and Duties), article 19 $\mathrm{N}^{\circ} 16$ (Freedom of Work and its protection) and Work Code, Article $2^{\circ}$ (2002)

\section{Employers Covered}

All employers; EOWW of 1999

refers to organizations of $100+$

All employers

Federal government departments, crown corporations, and other federally regulated agencies and organizations; Note that the majority of employers, including private employers, are regulated under provincial rather than federal law in Canada.

All employers

\section{Employment Practices Covered}

All stages of the employment relationship including, but not limited to, recruitment, selection, termination, training, and promotion.

Most employment practices including selection and appointment, promotions, employment opportunities, labor conditions, dismissal, and wages. Most employment practices including selection, performance appraisal, termination, and compensation.

The Constitution establishes the general nondiscrimination principle on the basis of race, color, sex, age, marital status, union membership 
France

Germany

Greece

\section{French Constitution of 1958}

International convention of the United

Nations (1965) ratified in 1971

International convention of the International Labor

Organization (1958) ratified in 1981

"The law concerning the fight against

racism" of 1972

"The law concerning worker's liberties in

organizations" of 1982

Treaty of Amsterdam of 1997

L. 122-45 from Labor Law

225-1 and 225-2 from the Penal Code

Allgemeines Gleichbehandlungsgesetz: General Equal Opportunity Law

Greek Law 3304 of 2005, equal treatment

Greek Law 3896 of 2010, on equal treatment between people in the labor market
All employers

All employers, except tendency

organizations (e.g., religious

organizations)

All employers status, religion, political opinions, nationality, and national or social origin. In March 2008, a new law went into effect (law \# 20,087). This new law defines discrimination as any action that is against the equal opportunity for all workers. A new regulation will specify the practices that are covered by the law.

Many employment practices including selection, access to training, pay, layoffs, transfers, and job classification.

All stages of the employment relationship including placing a job $\mathrm{ad}$, hiring and selection, definition of payment, performance appraisal and promotion, job-related training and job counseling, corporate health services, design of working conditions, social services, and dismissal.

Conditions for access to employment, to self-employment, or to occupation, including selection 
Indian Constitution

Article 15. Prohibition of discrimination on grounds

of religion, race, caste, sex, or place of birth

Article 16. Equality of opportunity in matters of

public employment

Article 39

Article 46

Article 335

Basic Law on Human Dignity and Liberty

Basic Law on the Freedom of Occupation

Women's Equal Rights Law of 1951

Equal Pay Law of 1996 criteria and recruitment conditions; promotion; access to all types and to all levels of vocational guidance, vocational training, advanced vocational training and retraining, including practical work experience, employment and working conditions; dismissals, pay, membership, and involvement in an organization of workers or employers, or any organization whose members carry on a particular profession, including the benefits provided for by such organizations; social protection, including social insurance and sanitary relief; social provisions; education; and access to disposal and to provision of benefits, which are provided to the public, including housing.
Government entities, public sector organizations, and organizations receiving government funding
All employers

All employers $6+$
Compensation, staffing, conditions of employment, promotion, training and development, dismissal, severance pay, retirement benefits. 
Equal Employment Opportunity of 1988

Italian Constitution of 1948 Article 3

Legislative decree 216 of 2003

Legislative decree 198 of 2006 (Equal Pay)

Law on Securing Equal Opportunity and Treatment between Men and Women in Employment of 1972

Law for Employment Promotion, etc. of the Disabled of 1960

Law Concerning Stabilization of Employment of Older Persons of 1971

Kenya

Kenyan Constitution Chapter 5, Section 82 HIV and AIDS Prevention and Control Act 14 The Persons with Disabilities Act 14 of 2003

The Employment Act of 2007 Cap 226.
All employers

All employers (exceptions for the Employment Act include the Armed Forces, Kenya police, National Youth Services, and employer dependents where the dependents are the only employees in a family undertaking).

All employers
Recruitment, selection, promotion, employment agencies, outplacement procedures, training, working conditions.

Wages, working hours, other working conditions.

Recruitment and hiring, assignment, promotion, demotion, training, fringe benefits, change in job type and employment status, encouragement of retirement, mandatory retirement age, dismissal and renewal of employment contract.

Recruitment and hiring.

Mandatory retirement, secure stable employment, and reemployment.

All employment practices.

The law covers a wide range of employment decisions including recruitment, training, promotion, termination and or allocation of terms and conditions of employment. Recruitment, hiring, training, placement, promotion, compensation, loans, mandatory retirement age, 
Act on Equal Employment and Support for Work-Family Reconciliation (formerly the Equal Employment Act of 1987)

The Act of Employment Promotion and Vocational Rehabilitation for the Disabled of 1990

The Aged Employment Promotion Act of 1991

The Basic Employment Policy Act of 1993

The Netherlands

Constitution, Article 1 of 2003 General Law Equal Treatment of 1994

New Zealand
All employers (employers of 500+ workers for affirmative action clause)

Employers with 50+ workers Government employees Employers with $300+$ employers

Not specified

All employers (except religious, philosophical, or political organizations)

All employers (exceptions are permitted where genuine occupational characteristics (GOQ) require a particular gender, age, or other prohibited characteristics. For example, a position in the National Security service requires New Zealand citizenship). retirement, and dismissal.

Recruitment, selection,

compensation, education,

training, job placement,

promotions, setting a

mandatory retirement age,

retirement, and dismissal.

Hiring, promotion, transfer,

education, and training.

Recruitment, hiring, and dismissal. Recruitment and hiring.

Recruitment, selection, employment agencies, dismissal, labor agreements, education before and during employment, promotion, and working conditions.

Refusal of employment, less favorable employment, conditions of work, superannuation, fringe benefits, training, promotion, transfer, termination, retirement, and resignation. The act also covers job advertisements. (The act also covers other areas of public life outside of employment, such as access to public spaces and education). 
South Africa

Constitution of the Republic of South Africa of 1996 Equity Act, No. 55, of 1998 as amended July 2014

Spain

Switzerland

Spanish Constitution, Article 14 of 1978

Law of Worker's Statute of 1980, 2005, Article 4.2 y 17

Organic Law for Effective Equality between

Women and Men of 2007, Article 1, 3, 4, 5, 6

Law of Basic Statute of Public Employee of 2005, Article 14.i

Bundesverfassung of 1999 (Swiss Federal Constitution)
Labour Relations Act, Act 66, of 1995 Employment

All employers except the National Defense Force, National Intelligence Agency, and South African Secret Service

All employers Bundesgesetz fiber die Beseitigung von

Benachteiligungen von Menschen mit

Behinderungen of 2002 (Federal Law for the Equal

Treatment of People with Disabilities)

Bundesgesetz fiber die Gleichstellung von Mann and

Frau of 1995 (Federal Law for the Equal Treatment
Public employers

All employers
Includes, but is not limited to,

recruitment procedures,

advertising, selection criteria,

appointment and appointment process, job classification and

grading, remuneration,

employment benefits, terms

and conditions of employment,

job assignments, working

environment and facilities,

training and development,

performance evaluation

systems, promotion, transfer,

demotion, disciplinary measure

other than dismissal, and

dismissal.

Recruitment, selection, promotion, compensation, training, temporal employment

companies, employment agencies, dismissal, labor agreements, collective bargaining, education before and during employment, health programs, and working conditions.

Includes pre- (particularly), during, and postemployment practices.

Includes pre-, during, and postemployment practices (i.e., 
of Men and Women)

Schweizerisches Zivilgesetzbuch of 1907 (Swiss Civil

$$
\text { Code) }
$$

Bundesgesetz betreffend die Erganzung des

Schweizerischen Zivilgesetzbuches -

Obligationenrecht of 1912 (Swiss Code of

Obligations)

Taiwan

Article 5 of the Employment Services Act of 1992

Gender Equality in Employment Law of 2002

Equal Employment Opportunity for Aborigines Act of 2001

People with Disabilities Rights Protection Act of 1970

Turkey
All employers

All employers

All employers

All levels of government, public schools and state-owned businesses (except for those located outside of Penghu, Jinmen and Lianjiang County)

All employers

All employers recruitment, sexual harassment, earnings, promotions, etc.).

Protection of employee personality and personal data throughout all stages of the employment process.

Staffing.

Recruitment, selection, promotion, job allocation, performance evaluation, promotion, training, compensation, benefits,

retirement, and dismissal.

Staffing for the jobs of contract employee; stationed police; mechanic, driver, janitor, cleaner; fee administrator; non-technical workers not requiring the qualifications of civil servants.

Staffing, occupational guidance assessment, occupational training, employment services, occupation redesign, and compensation and retirement.

Article 70 specifically covers selection for public institutions; other practices are implicitly covered including pay, promotion, 
Labor Law, Article 5 of 2003

UN's Convention on the Elimination of All Sorts of Discrimination Against Women Article 11

Prime Minister's office circular of 2004

Race Relations Act of 1976

Sex Discrimination Act of 1975

Employment Equality (Age) Regulations 2006 Equal Pay All ages, young and old Act of 1970

Disability Discrimination Act 1995 European

Community Directives

Equality Act of 2010
All employers (except sea

transportation, air transport, agricultural and forestry with less than 50 employees, home services, internships, professional athletes, rehabilitation workers, businesses with less than 3 workers, handmade art, jobs done at home, journalists)

All employers

Public employers

All employers, trade unions,

professional bodies, and

employment agencies

All employers, trade unions, professional bodies, and employment agencies and dismissal in other articles.

Performance appraisal, pay, promotion, and termination practices are implicitly covered; selection is not covered because the law only covers private sector employees who are already employed.

Generally all employment practices, including selection, promotion, termination, pay, performance appraisal, access to training, and treatment.

Selection.

Generally all employment practices: selection, promotion, termination, pay, performance appraisal, access to training, and treatment. 
Age Discrimination in Employment Act 1967

Americans with Disabilities Act 1990 and Rehabilitation Act 1973

Equal Pay Act 1963

Genetic Information Nondiscrimination Act of 2008
All public employers and private employers with $15+$ employees

Private employers with $20+$ employees, state and local governments

ADA covers private employers, state and local governments; Rehabilitation Act covers federal government; Virtually all employers
Range of employment decisions including hiring, compensation, terms, conditions, and employment privileges.

Prohibits discrimination against individuals 40+.

Prohibits discrimination against individuals with disabilities in employment decisions.

Prohibits discrimination against women in pay.

Prohibits use of genetic info in employment decisions. 


\section{TABLE 29.2}

Most Common Protected Classes

\begin{tabular}{|c|c|c|c|c|c|c|c|c|c|c|}
\hline Country & Race & Sex & $\begin{array}{l}\text { National/Ethnic } \\
\text { Origin }\end{array}$ & Color & Age & Religion & Disability & $\begin{array}{l}\text { Political } \\
\text { Opinion }\end{array}$ & $\begin{array}{l}\text { Sexual } \\
\text { Orientation }\end{array}$ & $\begin{array}{l}\text { Marital/Family } \\
\text { Status }\end{array}$ \\
\hline Belgium & $X$ & $X$ & $X$ & $X$ & $\mathrm{X}$ & $X$ & $X$ & $X$ & $\mathrm{X}$ & $X$ \\
\hline Canada & $X$ & $X$ & $X$ & $X$ & $X$ & $X$ & $X$ & $X$ & $X$ & $X$ \\
\hline Chile & $X$ & $\mathrm{X}$ & $X$ & $X$ & $X$ & $X$ & & $\mathrm{X}$ & & $X$ \\
\hline Germany & $X$ & $X$ & $X$ & & & $\mathrm{X}$ & $X$ & $\mathrm{X}$ & $\mathrm{X}$ & \\
\hline Greece & $X$ & & $X$ & & $\mathrm{X}$ & $\mathrm{X}$ & & & $\mathrm{X}$ & \\
\hline India & & $X$ & & & & & $\mathrm{X}$ & & & \\
\hline Japan & & $X$ & $X$ & & $X$ & $X$ & $X$ & $X$ & & \\
\hline Kenya & $X$ & $X$ & $X$ & $\mathrm{X}$ & & $X$ & $X$ & $X$ & & $X$ \\
\hline
\end{tabular}




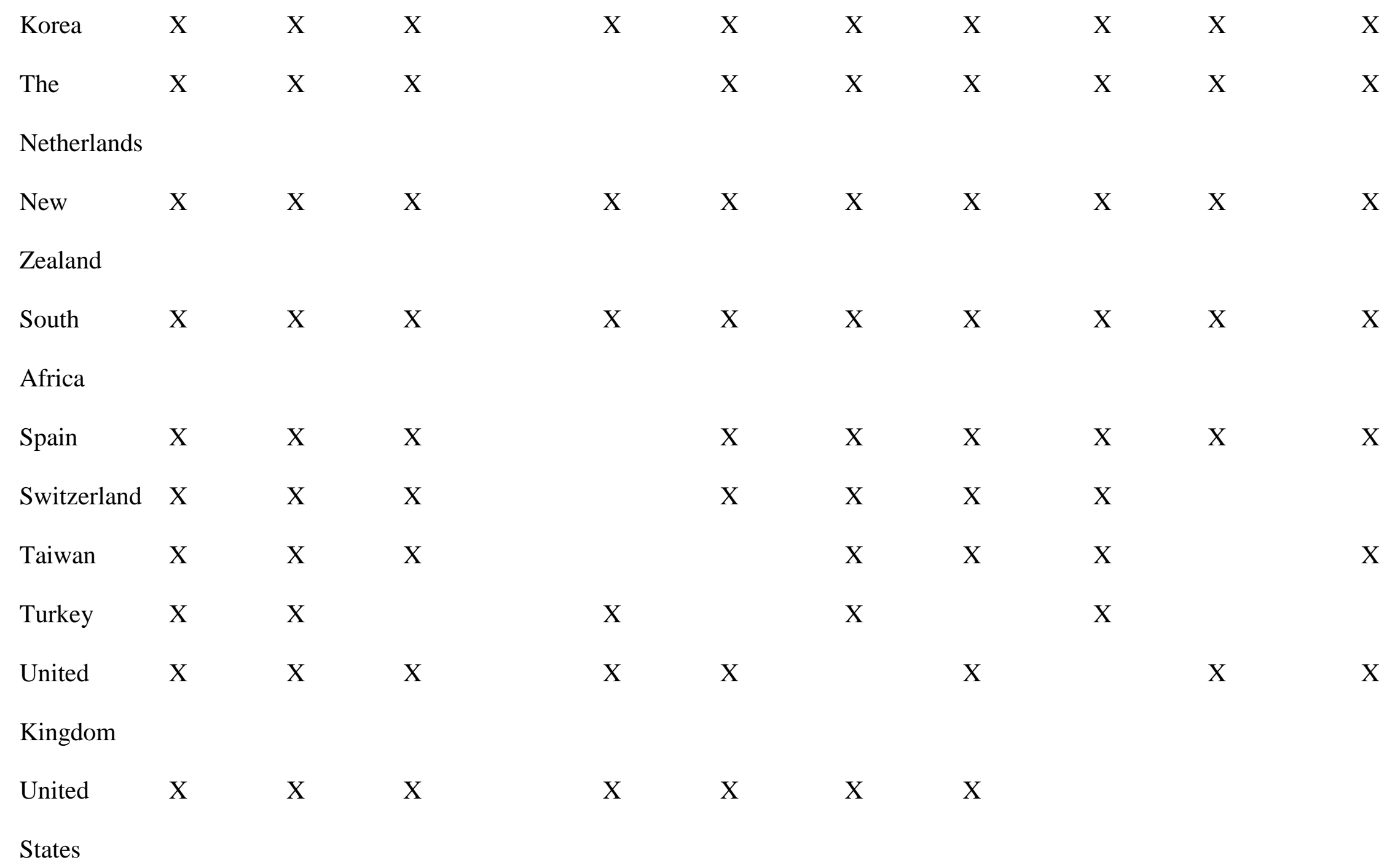


TABLE 29.3

\section{Other Protected Classes by Country}

\section{Country Other Protected Classes}

Australia Breastfeeding, family or career responsibilities, irrelevant criminal record, physical features, potential pregnancy, trade union or employer association activity, pregnancy and transgender status

Belgium Union membership, membership of other organizations, current or future health, wealth, physical or genetic characteristics, social status, and any other personal characteristic

Canada A conviction for which a pardon has been granted or a record suspended

Chile Union membership status

France Moral principles or beliefs, genetic characteristics, union activities or activities in a "mutuelle" (i.e., private supplementary insurance), physical appearance, family name, health, and place of residence

Germany Philosophy of life (i.e., moral principles/beliefs)

India $\quad$ Scheduled castes, scheduled tribes, and other backward classes

Israel Military service

Italy Personal and social conditions and language

Japan Social status

Kenya Tribe, local connection, and HIV/AIDS status

Korea Social status, region of birth, appearance, criminal record after punishment has been served, academic background, medical history, pregnancy, and physical conditions (e.g. appearance, height, weight) 
The Netherlands Philosophy of life (i.e., moral principles/beliefs), chronic disease, fulltime/part-time work, and type of contract

New Zealand Ethical belief (i.e., not having a religious belief), employment status

South Africa HIV status, conscience, belief, culture, birth, pregnancy, and language

Spain Social condition and membership to a labor union

Switzerland Socioeconomic status, way of life, and language

Taiwan Thought, provincial origin, appearance, facial features, union membership, status, and language

Turkey Philosophical belief (i.e., moral principles/beliefs), sect, and language

United Kingdom Persons who have undergone gender reassignment or intend to, pregnancy and maternity

United States Pregnancy and genetic information 
TABLE 29.4

Evidence Needed to Refute a Discrimination Claim, Consequences of Violation, and Permissibility of Preferential Treatment by

\section{Country}

Country

Australia

Belgium

\section{Evidence Needed to Refute a Claim}

Inherent requirements of the job, existence of special measures to eliminate discrimination,

occupational requirements, actions required by law, employment within small organizations, consistent beliefs (e.g., religious organizations or educational institutes). The statutes make no reference to the psychological concept of validity nor has it arisen in case law.

Statistical data or practical tests can be used as evidence.

\section{Consequences of Violation}

Injunction to stop the act, award of damages, order to the organization to redress the situation, variation, or cancellation of a contract or agreement that violates the law.

Mediation or binding judgment from civil court. Imprisonment and/or fines.

\section{Permissibility of Preferential} Treatment

Within-group norming is not banned and is used by some psychological testers as a means of complying with legislation (Myors, 2003). Targets may be used in some EEO plans, but explicit quotas are avoided.

Preferential treatment is permitted to remedy historical discrimination against a group. Quotas are required for board of director positions in public organizations and private organizations listed on the stock market, governmental positions of middle management level or higher, and scientific institutions, such that $1 / 3$ of these positions must be held by women. Both sexes must be 
Canada

Chile
The employer must demonstrate that the employment policy, practice, or procedure that is challenged is a bona fide occupational requirement.

Tribunals and courts are quite liberal in the evidence that they will accept from employers in defense of their employment practices. Empirical and statistical evidence generated by I-O psychologists (e.g., local validation studies) may be useful in defending employment practices, but courts and tribunals often lack the sophistication to make full use of such detailed and complex technical information.

Unclear, unless for sexual harassment or unionization suits. Empirical evidence not required.
Fines, payment for lost wages, reinstatement, and ordering of special programs.

Unknown. Currently, sexual harassment suits may result in monetary compensation and up to 3 years imprisonment. equally represented in election lists of political parties. Some organizations also utilize target numbers.

Preferential treatment permitted (mainly in the public sector).
Government has enacted an informal quota for women in minister positions; however, this has not crossed over into the private sector. 
France

Vague. Employer should present any information showing the decision is legitimate, nondiscriminatory, and based on objective information.

Germany

Needs to be based on job requirements.
Three years imprisonment and/or a fine for conviction in a criminal court. Discriminatory act may be annulled in a civil court and possibly result in financial compensation.
Employee has right to refuse to work while on payroll and sue employers for damages.

Considerable discussion about preferential treatment; politically, it is seen as undesirable. However, there are settings where it is used.

When parties present lists of candidates for regional and senatorial elections they are required to have an equal number of men and women (and, for some elections, an equal number of men and women must be elected).

There are quotas in one setting: at least $6 \%$ of workforce needs to be handicapped for organizations with more than 20 employees.

No formalization, but public authorities are to give preference to women and handicapped persons. 
Greece

India

Israel
Employer must show that there has been no breach of the principle of equal treatment.
Evidence of test reliability and validity, which can be based on validity generalization. In addition, the National Labor Court recently ruled that employers seeking to prove their innocence will be subject to less severe tests of selection validity to the extent that they are accused of discriminating against internal as opposed to external candidates; the logic being that employers typically have far greater information upon
The employer who infringes the laws about equal treatment on the grounds of racial or ethnic origin, religion or belief, disability, age or sex may be punished by imprisonment of 6 months up to 3 years with a penalty of 1,000 up to 5,000 euros.

At the discretion of the judge.

Preferential treatment to prevent or compensate for disadvantages linked to any of the protected classes.

Preferential treatment in the form of a relaxation of qualifying scores for protected groups in external recruitment is permitted;

however, a common standard is required for promotion. Not all members of protected groups are equally eligible, also dependent on social/economic status. Government positions also use quotas.

Small fines. Hiring, reinstatement, or Preferential treatment is required by career advancement of plaintiff, payment of back wages. public organizations and stateowned enterprises for women and minorities. $50 \%$ of board members of state-owned enterprises must be women. Preferential treatment is permitted in the private sector. 
which to base a selection decision when choosing among internal candidates.

Italy

Japan
Validity evidence not requested. Evidence to refute a claim is currently unclear.

The general guideline by the Ministry of Health, Labour and Welfare states that selection should be based solely on applicant aptitudes and abilities, and human rights should be respected during the selection process. To refute a claim of discrimination, the employer must show that the selection procedure is consistent with the guideline. Empirical validity evidence is not necessarily required, nor is the evidence from an on-site study or in other settings. Investigation is carried out on a case-by-case basis.
Unknown, most claims are resolved by sending the employer and employee to "regional equal opportunity counseling."

In the event that an employer is in violation of the law, the Ministry of Health, Labour and Welfare will give recommendations pursuant. If the employer has not complied with recommendations, the Ministry of Health, Labour and Welfare may make a public announcement of such violation. The employer who has failed to make a requested report or made a false report shall be liable to a civil fine of not more than 200,000 yen (approximately 2,400 USD).

For employment of individuals with disability, public employment security offices may order employers who do not meet quotas to create a plan for hiring individuals with disabilities. The employer who has failed to make the plan shall be liable to a civil
Preferential treatment permitted for women.

Preferential treatment of women is not required but softer forms of preference for women is permitted and supported by the state as long as it is intended to improve circumstances that impede the securing of equal opportunity and treatment between men and women in employment.

Quotas required for physically disabled workers. 
Kenya

Burden of proof rests with the employer.

Evidence required is vague, but generally must show that decisions were based on applicant aptitudes and abilities. Empirical validity evidence not required. fine of not more than 200,000

yen (approximately 2,400 USD).

The Ministry of Health, Labour

and Welfare may also make a

public announcement of

employers for not complying

with the law.

The Employment Act is vague

regarding penalties for

organizations that violate the

laws prohibiting discrimination.

These cases would be referred to

the industrial court for

adjudication of punitive or remunerative damages. In the

case of employer-employee

relationships, aggrieved parties

can lodge complaints (regarding

any violations of the

Employment Act) to labour

officers or complaints/suits to the Industrial Court. Section 88 of

the Employment Act limits

liability to fines not exceeding

50,000 Kenya shillings (US

$\$ 475$ ) or imprisonment to terms

not exceeding three months or to

both unless otherwise specified.
Preferential treatment is permitted and encouraged. The

Employment Act of 2007 notes expressly that taking affirmative action measures that are consistent with 'promoting equality or eliminating discrimination in the workplace" should not be considered as discrimination. 
Korea

The Netherlands

New Zealand
Show job relatedness, but specific method unclear.

Generally no validity evidence is requested because the validity of common psychological tests, such as tests for cognitive abilities, personality inventories and assessment center exercises, is taken for granted. Most claims concern direct discrimination or treatment discrimination (Commissie Gelijke Behandeling, 2006). Exceptions are clear-cut cases of indirect discrimination in which inappropriate job requirements were set.

Unclear, because few cases make it to court.

Genuine Occupational Qualifications (GOQ) - sex (e.g., physiological requirements, considerations as to decency or privacy, single-sex establishments, provision of welfare services); race (e.g., necessary for dramatic performance, cultural authenticity, work in ethnic restaurants, provision of welfare services)
National Humans Right Commission will make a binding conciliation resolution. Fines may be imposed.

Nonbinding judgment by the Commission of Equal Treatment and possibly judgment referral to a civil court.

Apology, payment or compensation, assurance that the discriminatory act will not be repeated, or referral to a Human Rights Tribunal for further judgment (e.g., a declaration that defendant has committed a breach, an order to undertake a training or any other program, compensatory damages, or "any other relief the Tribunal thinks fit").
Quotas required for disabled. Preferential treatment for aged and "semi-aged" for priority occupations.

Preferential treatment is permitted for women, ethnic minorities, and persons with disability or chronic illness (only in the case of equal qualification and use of preferential treatment must be mentioned in the job description).

Preferential treatment is currently being explored. It appears to be permitted (and may be soon applied to the Mäori population, given recent formulation of Treaty principles which state that the Crown has a duty to actively protect Mäori interest and to redress past injustices). 
South Africa

Spain

Switzerland

Taiwan

Turkey
Qualitative and empirical data can be brought to bear to support validity.

Fines or possible cancellation of government contracts.

Recent laws may lead to greater focus on empirical evidence; up until now, validity of tests was taken for granted.

\section{Empirical evidence not generally} presented or required.

Provide evidence of job relatedness.
Compensation, rejection of the decision, and subsequent application of the court decision, repetition of the selection process with new procedures.

Courts can award damages including payment of owed earnings and payment of compensation and satisfaction.

Fines may be imposed.

Reinstatement, back pay, and/or monetary damages.
Preferential treatment is permitted and applied. Racial quotas are legal and practiced by many large employers. The practical implication is that in the South African context it is legal to use race norming, or within-group top-down selection strategies, to address affirmative action needs of organizations.

Preferential treatment for women in some cases.

Preference is permitted but not required.

Quotas required for aborigine peoples and individuals with disabilities (quotas differ for different organizations, areas of the country, and positions).

Preferential treatment is not permitted 
United Kingdom

United States
Show that requirement is justified. The employer can show that they took all "reasonable" steps to prevent discrimination. No impact cases involving tests have reached the stage of a court decision, so there is as yet no requirement of validity evidence.

Evidence that the challenged practice is job-related for the position in question and consistent with business necessity (largely through validity studies).
Court has discretion. Compensation to the plaintiff. Formal investigation by governing bodies that can recommend changes in procedures.

Upon a finding of discrimination, a judge can specify "make whole" remedies, such as back pay, hiring, or reinstatement. There are no punitive damages absent a finding of intentional discrimination.
Employers may give preferential treatment to members of underrepresented groups so long as they are equally well qualified.

1991 amendments to Title VII of Civil Rights Act prohibit preferential treatment, specifically in the form of adjusting scores or using separate norms for minority group members. Preferential treatment is permitted after a finding of discrimination as part of a judicially ordered remedy. 